\title{
Insights into hydroxyl measurements and atmospheric oxidation in a California forest
}

\author{
J. Mao ${ }^{1,2}$, X. Ren ${ }^{3}$, L. Zhang ${ }^{4}$, D. M. Van Duin ${ }^{4}$, R. C. Cohen ${ }^{5}$, J.-H. Park ${ }^{6}$, A. H. Goldstein ${ }^{6}$, F. Paulot ${ }^{7, *}$, \\ M. R. Beaver ${ }^{7, * *}$, J. D. Crounse ${ }^{7}$, P. O. Wennberg ${ }^{7}$, J. P. DiGangi ${ }^{8, * * *}$, S. B. Henry ${ }^{8}$, F. N. Keutsch ${ }^{8}$, C. Park ${ }^{9, * * *}$, \\ G. W. Schade ${ }^{9}$, G. M. Wolfe ${ }^{10, * * * *}$, J. A. Thornton ${ }^{10}$, and W. H. Brune ${ }^{4}$ \\ ${ }^{1}$ Program in Atmospheric and Oceanic Sciences, Princeton University, Princeton, NJ, USA \\ ${ }^{2}$ Geophysical Fluid Dynamics Laboratory, NOAA, Princeton, NJ, USA \\ ${ }^{3}$ Air Resources Laboratory, NOAA, Silver Spring, MD, USA \\ ${ }^{4}$ Department of Meteorology, Pennsylvania State University, University Park, PA, USA \\ ${ }^{5}$ Department of Chemistry and Department of Earth and Planetary Science, University of California Berkeley, Berkeley, \\ CA, USA \\ ${ }^{6}$ Department of Environmental Science, Policy, and Management, University of California Berkeley, Berkeley, CA, USA \\ ${ }^{7}$ Environmental Science and Engineering, California Institute of Technology, Pasadena, CA, USA \\ ${ }^{8}$ Department of Chemistry, University of Wisconsin-Madison, Madison, Wisconsin, USA \\ ${ }^{9}$ Department of Atmospheric Sciences, Texas A\&M University, College Station, TX, USA \\ ${ }^{10}$ Department of Atmospheric Sciences, University of Washington, Seattle, WA, USA \\ *now at: School of Engineering and Applied Sciences, Harvard University, Cambridge, MA, USA \\ ** now at: National Exposure Research Laboratory, Environmental Protection Agency, Research Triangle Park, NC, USA \\ *** now at: Department of Civil and Environmental Engineering, Princeton University, Princeton, NJ, USA \\ **** now at: Department of Atmospheric Environmental Sciences, Pusan National University, South Korea \\ ****** now at: Department of Chemistry, University of Wisconsin-Madison, Madison, Wisconsin, USA
}

Correspondence to: J. Mao (jingqiu.mao@noaa.gov)

Received: 22 February 2012 - Published in Atmos. Chem. Phys. Discuss.: 2 March 2012

Revised: 17 August 2012 - Accepted: 28 August 2012 - Published: 7 September 2012

\begin{abstract}
The understanding of oxidation in forest atmospheres is being challenged by measurements of unexpectedly large amounts of hydroxyl $(\mathrm{OH})$. A significant number of these $\mathrm{OH}$ measurements were made by laser-induced fluorescence in low-pressure detection chambers (called Fluorescence Assay with Gas Expansion (FAGE)) using the Penn State Ground-based Tropospheric Hydrogen Oxides Sensor (GTHOS). We deployed a new chemical removal method to measure $\mathrm{OH}$ in parallel with the traditional FAGE method in a California forest. The new method gives on average only $40-60 \%$ of the $\mathrm{OH}$ from the traditional method and this discrepancy is temperature dependent. Evidence indicates that the new method measures atmospheric $\mathrm{OH}$ while the traditional method is affected by internally generated $\mathrm{OH}$, possibly from oxidation of biogenic volatile organic compounds. The improved agreement between $\mathrm{OH}$ measured by this new
\end{abstract}

technique and modeled $\mathrm{OH}$ suggests that oxidation chemistry in at least one forest atmosphere is better understood than previously thought.

\section{Introduction}

Forests emit copious amounts of biogenic volatile organic compounds (BVOCs) that react with ozone $\left(\mathrm{O}_{3}\right)$ and the hydroxyl radical $(\mathrm{OH})$, thus creating many more oxidized volatile and semi-volatile chemicals. In the absence of nitric oxide (NO), a condition typical for remote forests, the oxidation chemistry removes ozone, regenerates some $\mathrm{OH}$, removes hydrogen oxides by reactions among hydroperoxyl $\left(\mathrm{HO}_{2}\right)$ and organoperoxyl $\left(\mathrm{RO}_{2}\right)$ radicals, and produces semi-volatile secondary organic aerosols (SOA). The

Published by Copernicus Publications on behalf of the European Geosciences Union. 
extensive global coverage of remote forests (Hansen et al., 2003) means that atmospheric chemistry of remote forests influences the global oxidation capacity, ozone budget, SOA distribution, and atmospheric lifetime of methane.

$\mathrm{OH}$ plays a central role in these atmosphere-biosphere interactions because $\mathrm{OH}$ oxidizes most of the BVOCs emitted in remote forests. However, several field studies in terrestrial vegetation have shown that measured $\mathrm{OH}$ exceeds modeled $\mathrm{OH}$ by a factor of 2 to 10 (Tan et al., 2001; Carslaw et al., 2001; Thornton et al., 2002; Lelieveld et al., 2008; Ren et al., 2008; Hofzumahaus et al., 2009; Whalley et al., 2011), thus indicating the chemistry of BVOCs is poorly understood. This discrepancy presents a challenge: the $\mathrm{OH}$ production rate needed to maintain these measured $\mathrm{OH}$ abundances is 2-10 times larger than current model mechanisms can support and would produce large amounts of $\mathrm{HO}_{2}$ and $\mathrm{RO}_{2}$ radicals (Faloona et al., 2001; Tan et al., 2001; Stone et al., 2011). However, such high levels of $\mathrm{HO}_{2}$ and $\mathrm{RO}_{2}$ were not observed (Ren et al., 2008; Hofzumahaus et al., 2009; Whalley et al., 2011). These OH discrepancies helped motivate the development of new improved isoprene oxidation mechanisms, but they generally have not been able to explain the $\mathrm{OH}$ measurements (Butler et al., 2008; Hofzumahaus et al., 2009; Paulot et al., 2009a; Paulot et al., 2009b; Peeters et al., 2009; Peeters and Müller, 2010).

An alternate explanation is that our $\mathrm{OH}$ measurements are wrong in forests when alkene chemistry dominates. The majority of all $\mathrm{OH}$ measurements in and above remote forests have been made with laser induced fluorescence in lowpressure detection cells (often called Fluorescence Assay with Gas Expansion (FAGE)) (Hard et al., 1984), and several of them by the Penn State instrument, the Ground-based Tropospheric Hydrogen Oxides Sensor (GTHOS). In this method, air is sampled through a pinhole. The $\mathrm{OH}$ absorbs light from a tunable, pulsed UV laser and then its fluorescence is detected tens of nanoseconds later with a gated detector. The $\mathrm{OH}$ fluorescence signal is separated from the background signal by periodically shifting the laser wavelength from an $\mathrm{OH}$ absorption line to nearby wavelengths where $\mathrm{OH}$ does not absorb (off-line). Interferences from $\mathrm{OH}$ generated by the laser have been ruled out by laboratory and field studies for GTHOS (Ren et al., 2004) and the fluorescence spectrum of the signal matches that of $\mathrm{OH}$. However, it is possible that BVOC oxidation products form $\mathrm{OH}$ after entering the instrument inlet and that this conversion is responsible for the inexplicably high $\mathrm{OH}$ measurements in our prior studies.

To test this possibility, we added a second method for detecting $\mathrm{OH}$ for a multi-investigator field campaign in a Sierra Nevada forest during summer 2009. In the second method, a chemical that removes $\mathrm{OH}$ was periodically added to the air just before it was sampled by the instrument. This zeroing method has been used previously by Chemical Ionization Mass Spectrometer instruments (Tanner et al., 1997) with the chemical being either propane or hexafluoropropene $\left(\mathrm{C}_{3} \mathrm{~F}_{6}\right)$.
We primarily used $\mathrm{C}_{3} \mathrm{~F}_{6}$ because of its chemical and optical properties (Dubey et al., 1996), but also used propane during one day of the study. Here, we discuss the comparison of these two methods of determining OH from GTHOS with a photochemical box model that has recent updates in BVOC oxidation mechanisms. Simultaneous measurements of the $\mathrm{OH}$ reactivity and of the hydroperoxyl radical $\left(\mathrm{HO}_{2}\right)$ provide additional information about the comparisons.

\section{Methodology}

\subsection{Site description}

The Biosphere Effects on Aerosols and Photochemistry Experiment II (BEARPEX09) was designed to examine the photochemistry in and above the forest canopy with a wide range of state-of-the-art measurements. The field site was a Ponderosa pine plantation near the Blodgett Forest Research Station (BFRS) in the California Sierra Nevada Mountains. BFRS is located $75 \mathrm{~km}$ northeast of Sacramento, CA $\left(1315 \mathrm{~m}\right.$ a.s.l., $\left.38.9^{\circ} \mathrm{N}, 120.6^{\circ} \mathrm{W}\right)$. The mean canopy height was $8.9 \mathrm{~m}$. The site included one $15 \mathrm{~m}$ walk-up tower in the south and one $18 \mathrm{~m}$ scaffolding tower in the north. Two towers were separated by $10 \mathrm{~m}$. Most instruments were installed on the north tower, including meteorological sensors for temperature, pressure, relative humidity and wind speed. An electric boom lift, on which $\mathrm{OH}, \mathrm{HO}_{2}$ and $\mathrm{OH}$ reactivity instruments were installed, was adjacent to the north tower. A propane generator was located $125 \mathrm{~m}$ north of the north tower. The sampling site could be intermittently influenced by generator plumes at night (but not daytime). Typical meteorological conditions at the site are characterized by a dry season from May to September with high daytime temperature, low rainfall and low humidity, and consistent southwesterly (upslope) wind during the day and northeasterly (downslope) wind at night.

Local biogenic VOC emission at BFRS consists mainly of 2-methyl-3-buten-2-ol (MBO) (Schade et al., 2000), monoterpenes (particularly $\beta$-pinene) (Bouvier-Brown et al., 2009a), sesquiterpenes (Bouvier-Brown et al., 2009b), and related oxygenated compounds (Holzinger et al., 2005). Recent studies also identified a number of previously unmeasured VOCs, such as sesquiterpenes, methyl chavicol (estragole), and related oxygenated compounds at BFRS (Bouvier-Brown et al., 2009c). Due to consistent southwesterly wind during daytime, BFRS is influenced by anthropogenic emissions from the Greater Sacramento Area $(\sim 75 \mathrm{~km} \mathrm{SW})$ and biogenic emissions from a $20-25 \mathrm{~km}$ wide band of oak woodlands ( $\sim 30 \mathrm{~km} \mathrm{SW}$ ) during daytime (Dreyfus et al., 2002). The biogenic plume usually arrives at 12:0014:00 Pacific Standard Time (PST) with relatively high levels of isoprene and its oxygenated products. The anthropogenic plume arrives at late afternoon between 18:00-20:00 PST with elevated levels of anthropogenic tracers (LaFranchi et 
al., 2009). Thus the mixture of biogenic and anthropogenic influences changes during the day.

\subsection{Two methods of $\mathrm{OH}$ measurements}

Observations of $\mathrm{OH}, \mathrm{HO}_{2}$ and $\mathrm{OH}$ reactivity were made from 20 June (day of year $(\mathrm{DOY})=171$ ) to 30 July (DOY $=211$ ) of 2009. $\mathrm{OH}$ and $\mathrm{HO}_{2}$ were measured by the Penn State Ground-based Tropospheric Hydrogen Oxides Sensor (GTHOS) (Faloona et al., 2004) and OH reactivity was measured by the $\mathrm{OH}$ reactivity instrument from the same group (Mao et al., 2009). GTHOS and OH reactivity instrument were both installed on the lift. This lift was manually controlled to move from the ground to $17 \mathrm{~m}$ high (stopped at various heights) for the purpose of measuring vertical profile of radicals. Vertical profiling was conducted two to three times per day. For the rest of the time, the lift was mainly kept at a height of $9 \mathrm{~m}, 12 \mathrm{~m}$, or $15 \mathrm{~m}$. Little variability was found for $\mathrm{OH}, \mathrm{HO}_{2}$ and $\mathrm{OH}$ reactivity at these three heights (less than $20 \%$ ), which is consistent with a model study (Wolfe et al., 2011), so we here use the measurements from all three heights to improve measurement statistics.

$\mathrm{OH}$ was measured by Laser Induced Fluorescence (LIF) technique in a low pressure chamber (Faloona et al., 2004). $\mathrm{OH}$ absorbs laser light at a wavelength near $308 \mathrm{~nm}$ and the excited $\mathrm{OH}$ emits fluorescence in the wavelength range from $307 \mathrm{~nm}$ to $311 \mathrm{~nm}$ simultaneously. The fluorescence photons are captured by a gated microchannel plate (MCP) detector, which is set perpendicular to the airflow and the laser beam. $\mathrm{HO}_{2}$ is converted to $\mathrm{OH}$ via its reaction with $\mathrm{NO}$ followed by the LIF measurement in a second detection axis of the GTHOS system. The laser system consists of a dye laser that is pumped by a diode-pumped Nd:YAG laser (SpectraPhysics, X30SC-1060A) at $3 \mathrm{kHz}$ pulse repetition. The output of the dye laser is used to excite $\mathrm{OH}$. Tuning of the laser wavelength is achieved by an etalon. The etalon is tuned so that the laser wavelength remains on-line of an $\mathrm{OH}$ absorption line for $10 \mathrm{~s}$ and then nearby off-line wavelengths for $10 \mathrm{~s}$ to measure the background. The difference in the average on-line and average off-line signals is the $\mathrm{OH}$ fluorescence signal, which is converted to an $\mathrm{OH}$ mixing ratio by calibrations with a known amount of $\mathrm{OH}$. The measured $\mathrm{OH}$ in this approach is called "OHwave".

The second approach to measure $\mathrm{OH}$ is chemical modulation using the signal difference with and without the addition of high-purity gaseous hexafluoropropene $\left(\mathrm{C}_{3} \mathrm{~F}_{6}\right)$ to remove $\mathrm{OH}$ prior to the detection by LIF (Fig. 1). $\mathrm{C}_{3} \mathrm{~F}_{6}$ is ideal as an $\mathrm{OH}$ scrubber as it reacts fast enough to remove $\mathrm{OH}$ and its optical absorption around $308 \mathrm{~nm}$ is also negligible (Dubey et al., 1996). In order to inject $\mathrm{C}_{3} \mathrm{~F}_{6}$ upstream of inlet flow, a $4 \mathrm{~cm}$-long aluminum cylinder (OD $5.1 \mathrm{~cm}$ and ID $2.5 \mathrm{~cm}$ ) was installed on top of the GTHOS inlet. A 5-cm long PFA tube with ID of $1.9 \mathrm{~cm}$ was installed inside this cylinder to reduce the residence time of ambient air inside the cylinder to $\sim 100 \mathrm{~ms}$. The flow through cylinder consisted of 7000

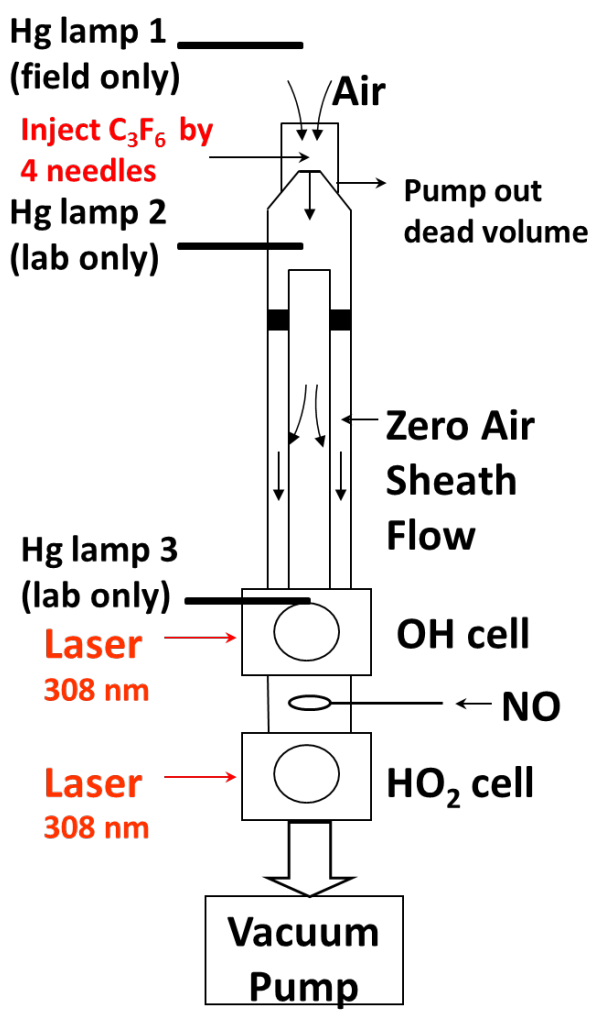

Fig. 1. Schematic diagram of the detection system cross section. Gaseous $\mathrm{C}_{3} \mathrm{~F}_{6}$ was injected simultaneously through four $0.25 \mathrm{~mm}$ needles pointed toward the center, which were located about $4 \mathrm{~cm}$ above the inlet. $\mathrm{Hg}$ lamp 1 was deployed in the field to ensure that the $\mathrm{C}_{3} \mathrm{~F}_{6}$ or propane removed most of the externally generated $\mathrm{OH}$. $\mathrm{Hg}$ lamp 2 and 3 were installed only in the lab to determine how much $\mathrm{OH}$ is removed internally with the external $\mathrm{C}_{3} \mathrm{~F}_{6}$ addition. Hg lamp 2 was added just under the inlet cone and was shrouded so that it shone only across the flow and not up or down. $\mathrm{Hg}$ lamp 3 was inserted in the ring just above the $\mathrm{OH}$ detection cell and shone light into the sheath flow and the detection axis.

standard cubic centimeters per minute $(\mathrm{sccm})$ that was sampled by the inlet and another $2000 \mathrm{sccm}$ that was pulled by a vacuum pump through a ring-shaped gap between the tube and the inlet. This "ring" flow minimized the sampling of air that had been near the cylinder walls. Gaseous $\mathrm{C}_{3} \mathrm{~F}_{6}$ was injected simultaneously through four $0.25 \mathrm{~mm}$ needles pointed toward the center, which were located about $1 \mathrm{~cm}$ above the inlet (Fig. 1). $\mathrm{C}_{3} \mathrm{~F}_{6}$ was added for two minutes every four minutes; four different flow rates $(1.1,1.7,2.2$, and $3.3 \mathrm{sccm})$ were used during the study. An $\mathrm{N}_{2}$ flow of $100 \mathrm{sccm}$ was continuously added through the needles so that the periodic $\mathrm{C}_{3} \mathrm{~F}_{6}$ addition did not perturb the flow. This injection system, without $\mathrm{C}_{3} \mathrm{~F}_{6}$ addition, caused negligible $\mathrm{OH}$ loss according to several laboratory and field tests in which the injection system was removed for an hour and the OHwave signal did not change. On one day, propane was substituted for $\mathrm{C}_{3} \mathrm{~F}_{6}$ with similar results. The difference in signal with and without the 
addition of $\mathrm{C}_{3} \mathrm{~F}_{6}$ is used to calculate the measured $\mathrm{OH}$ that is defined as "OHchem".

In some instrument configurations, $\mathrm{OH}$ can be generated by the $308 \mathrm{~nm}$ laser beam inside the instrument. This $\mathrm{OH}$ is produced in some LIF systems, including a previous version of GTHOS, from the photolysis of ozone followed by the reaction of excited state oxygen atoms with $\mathrm{H}_{2} \mathrm{O}$ (Smith and Crosley, 1990). The OH generation by the laser can be tested by varying the laser power because laser-generated $\mathrm{OH}$ requires two photons - one to make $\mathrm{OH}$ and one to detect it - so that the amount of detected laser-generated $\mathrm{OH}$ depends on the square of the laser power. The current version of GTHOS was designed and tested to minimize laser-generated $\mathrm{OH}$. Also, a filter wheel has been used to suddenly attenuate the laser power to the $\mathrm{OH}$ detection axis so that the laser power dependence of the $\mathrm{OH}$ signal can always be tested.

\subsection{Model simulation}

A photochemical box model is used to examine the $\mathrm{OH}$ and $\mathrm{HO}_{2}$ measurements during BEARPEX09. The model uses the Regional Atmospheric Chemistry Mechanism, Version 2 (RACM2) (Henderson et al., 2011). Compared to the original RACM mechanism (Stockwell et al., 1997), RACM2 now includes 117 total species (77 in RACM) and incorporates large number of updates from Master Chemical Mechanism (MCM), JPL and IUPAC kinetics updates. The original version of RACM2 is further modified with isoprene nitrate chemistry (Paulot et al., 2009a) and isoprene epoxide chemistry (Paulot et al., 2009b), reduced unimolecular isomerization of isoprene hydroxyperoxy radicals (Peeters et al., 2009; Peeters and Müller, 2010; Crounse et al., 2011), terpene oxidation (Wolfe and Thornton, 2011), and MBO oxidation (Carrasco et al., 2007; Steiner et al., 2007; Chan et al., 2009). Photolysis rates were calculated by the Tropospheric Ultraviolet and Visible (TUV) radiation model (http: //www.acd.ucar.edu/TUV) and then scaled based on the local Photosynthetically Active Radiation (PAR) measurements. The model was constrained by measured meteorological parameters and chemical species (Table S1) and run one day for each data point, long enough to allow most calculated species to reach steady state but short enough to prevent the buildup of secondary products. Dry deposition was assumed for aldehydes and peroxides with a lifetime of 30 hours (Karl et al., 2010). This box model is similar to other commonly used box models. The model simulation used in the main body represents the best knowledge of the current understanding of biogenic oxidation chemistry. In addition, we have conducted model simulations with a variety of chemical mechanisms, which can be found in the supplement material.

Following the discovery by Fuchs et al.(2011) that $\mathrm{RO}_{2}$ from BVOCs can be detected as $\mathrm{HO}_{2}$ in LIF systems, we conducted $\mathrm{RO}_{2}$ interference tests in the laboratory with the same configuration deployed in the field for isoprene and several alkenes. The relative detection sensitivities are roughly
0.6 , with a range from 0.45 to 0.75 . Therefore we corrected $\mathrm{HO}_{2}$ measurements based on modeled isoprene peroxy radical (ISOP), peroxy radicals from MACR (MACRO2 and MAO3) and peroxy radical from MVK (MVKO2) with a relative sensitivity of $0.6 . \mathrm{RO}_{2}$ from $\mathrm{MBO}$ is not included, as measurements from MBO hydroperoxide indicates a much lower level of MBO peroxy radical than model calculations, likely due to unknown removal mechanism of $\mathrm{MBO} \mathrm{RO}_{2}$. We find that modeled $\mathrm{HO}_{\mathrm{x}}$ concentrations are relatively insensitive to the level of $\mathrm{MBO} \mathrm{RO}_{2}$.

\section{Results}

\subsection{Diurnal cycle}

Figure 2 shows the diurnal cycle of measured and modeled OH between 20 June and 30 July 2009 near the Blodgett Forest Research Station (BFRS). While OHwave and OHchem show a similar diurnal pattern, OHchem is only about 40 $60 \%$ of OHwave during daytime and $50 \%$ at night, on average. The question is then "Which one is the real $\mathrm{OH}$ ?"

We first quantify the extent to which external $\mathrm{OH}$ is removed with the external $\mathrm{C}_{3} \mathrm{~F}_{6}$ addition. Here external $\mathrm{OH}$ is ambient atmospheric $\mathrm{OH}$ before sampling and internal $\mathrm{OH}$ is $\mathrm{OH}$ that is generated inside the low-pressure region of GTHOS, from the inlet to the detection axis. A mercury lamp with $185 \mathrm{~nm}$ UV light emission was placed on the outer wall of the aluminum cylinder (Hg lamp 1 in Fig. 1). This lamp was turned on for 10 minutes every $4 \mathrm{~h}$ to produce $\mathrm{OH}$ by photolyzing ambient water vapor: $\mathrm{H}_{2} \mathrm{O}+h v \rightarrow \mathrm{OH}+\mathrm{H}$, where $\mathrm{H}$ immediately combines with $\mathrm{O}_{2}$ to form $\mathrm{HO}_{2}$. This externally generated $\mathrm{OH}$ signal was two orders of magnitude larger than ambient $\mathrm{OH}$ and $\mathrm{C}_{3} \mathrm{~F}_{6}$ addition removed about $80 \%$ at the $1.1 \mathrm{sccm} \mathrm{C}_{3} \mathrm{~F}_{6}$ flow rate and $94 \%$ at $3.3 \mathrm{sccm}$ (Fig. 3). OHchem data were corrected for incomplete removal in the analysis program. The near-complete removal of $\mathrm{OH}$ generated by the $\mathrm{Hg}$ lamp 1 is the primary evidence that $\mathrm{OHchem}$ is a measure of the real $\mathrm{OH}$ and that $\mathrm{OHwave}$ is influenced by $\mathrm{OH}$ generated within GTHOS.

We then quantify the internal $\mathrm{OH}$ removal with the external $\mathrm{C}_{3} \mathrm{~F}_{6}$ addition, by generating $\mathrm{OH}$ in two locations above the $\mathrm{OH}$ detection axis during laboratory studies. One lamp was placed just below the inlet (Hg lamp 2 in Fig. 1), generating $\mathrm{OH}$ in the sampled flow and a second lamp was added just above the detection axis (Hg lamp 3 in Fig. 1) generating $\mathrm{OH}$ in the detection axis itself. The lamp near the inlet was shrouded so that its light shone only across the flow tube and not up into the inlet or down into the detection cell. $\mathrm{C}_{3} \mathrm{~F}_{6}$ addition removed $3-10 \%$ of the $\mathrm{OH}$ generated in the $\mathrm{OH}$ detection axis but removed $25-60 \%$ of the $\mathrm{OH}$ generated just below the instrument pinhole inlet, depending on the $\mathrm{C}_{3} \mathrm{~F}_{6}$ flow. Laboratory studies provide solid evidence that internal $\mathrm{OH}$ is being generated primarily near and in the $\mathrm{OH}$ detection axis and quantify the amount of internal $\mathrm{OH}$ 


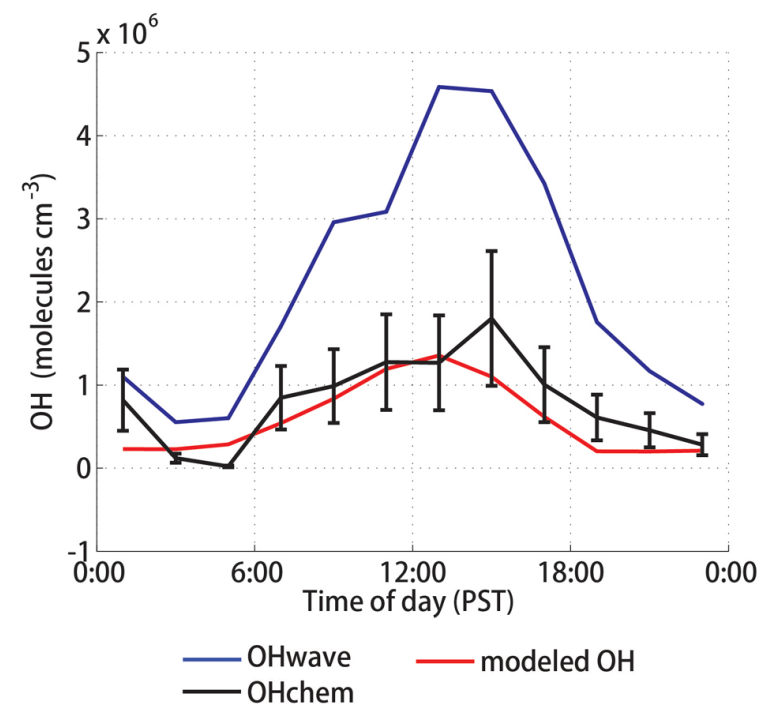

Fig. 2. Diurnal cycle of measured and modeled $\mathrm{OH}$ between 20 June and 30 July 2009 near the Blodgett Forest Research Station (BFRS). "OHwave" (blue line) is statistically different from "OHchem" (black line) and modeled $\mathrm{OH}$ (red line). The model incorporates the current understanding of BVOC oxidation chemistry (see text for details). The vertical bars indicate OHchem's absolute uncertainty of $\pm 45 \%$ ( $2 \sigma$ confidence), which comes from combining the uncertainty from the internally generated $\mathrm{OH}$ removed by the $\mathrm{C}_{3} \mathrm{~F}_{6}$ addition used to measure OHchem $( \pm 20 \%)$ and the absolute uncertainty of the $\mathrm{OH}$ measurements $( \pm 40 \%$ at $2 \sigma$ confidence). Note that $\mathrm{OHchem}$ here is corrected by 0.80 to account for the removal of internal $\mathrm{OH}$ by $\mathrm{C}_{3} \mathrm{~F}_{6}$ addition (see supplemental material). OHchem is similar to modeled $\mathrm{OH}$, indicating a generally good understanding of oxidation in this forest atmosphere.

remaining, which is $0.83 \pm 0.08$. To account for the small internal $\mathrm{OH}$ removal, the difference between $\mathrm{OH}$ without and with $\mathrm{C}_{3} \mathrm{~F}_{6}$ must be multiplied by $(0.80 \pm 0.12)$ (see supplementary material). We retain the name "OHchem" for this corrected value, which is a quantitative measure of the real atmospheric $\mathrm{OH}$.

Three lines of evidence indicate that the signals observed in BEARPEX09 were not laser generated. First, the observed $\mathrm{OH}$ signal was proportional to the laser power, not quadratic. Second, the difference for $\mathrm{OH}$ removal for the internal $\mathrm{OH}$ generation between near the inlet and near the detection axis indicates that the difference between OHwave and OHchem is not generated by the UV laser in the detection axis. Third, a recent laboratory test for $\alpha$-pinene, MBO, and $\beta$-pinene under high ozone showed no laser power dependence of the $\mathrm{OH}$ signal with $\mathrm{C}_{3} \mathrm{~F}_{6}$ on or off. Thus, any differences observed between OHwave and $\mathrm{OHchem}$ are not due to lasergenerated $\mathrm{OH}$.

Daytime OHchem is in much better agreement with modeled $\mathrm{OH}$ than is OHwave (Fig. 2). The ratio of OHwave to modeled $\mathrm{OH}$ is $3.1 \pm 0.7$, while ratio of $\mathrm{OHchem}$ to modeled $\mathrm{OH}$ is $1.4 \pm 0.3$, both for hourly averages. The difference

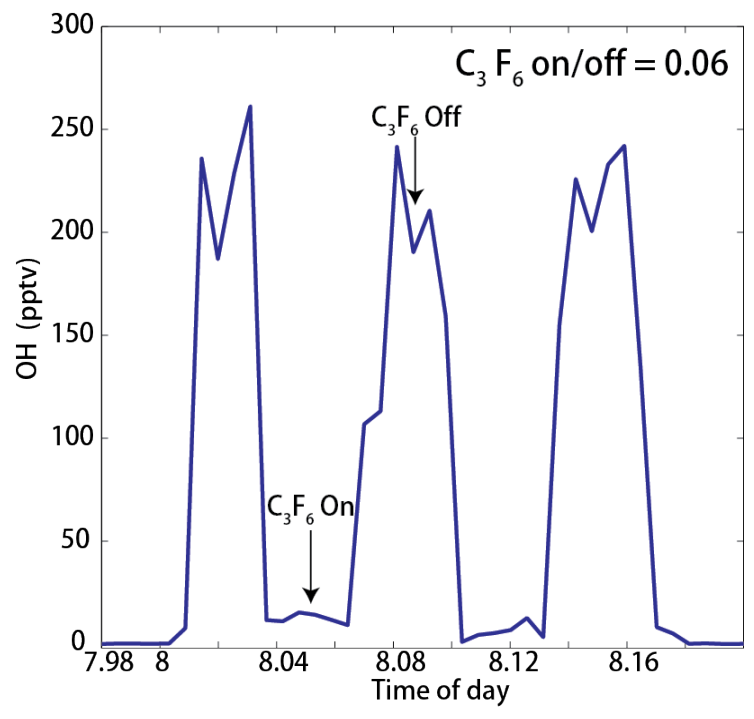

Fig. 3. Example of $\mathrm{OH}$ measurement with an external mercury lamp (Hg lamp 1 in Fig. 1) producing $\mathrm{OH}$ and periodic $\mathrm{C}_{3} \mathrm{~F}_{6}$ addition ( $3.3 \mathrm{sccm})$. The large $\mathrm{OH}$ value is when $\mathrm{C}_{3} \mathrm{~F}_{6}$ is not added and the small value occurs when it is. The removal efficiency for this example is $94 \%$.

between OHwave and the model is statistically significant while the difference between $\mathrm{OHchem}$ and the modeled $\mathrm{OH}$ is not. Thus the modeled $\mathrm{OH}$ is consistent with the OHchem.

Nighttime OHchem also agrees better with modeled $\mathrm{OH}$. A discrepancy between measured and modeled $\mathrm{OH}$ at night has been widely observed with the Penn State Groundbased Tropospheric Hydrogen Oxides Sensor (GTHOS) for OHwave, for which the measurement is typically 3 to 10 times the modeled nighttime $\mathrm{OH}$ (Faloona et al., 2001). Since OHchem $\left(2.7 \pm 1.8 \times 10^{5}\right.$ molecules $\left.\mathrm{cm}^{-3}\right)$ is somewhat less than half of OHwave $\left(7.5 \pm 0.8 \times 10^{5}\right.$ molecules $\left.\mathrm{cm}^{-3}\right)$ during night (22:00 to 04:00 PST), the discrepancy between measured and modeled $\mathrm{OH}\left(2.4 \pm 0.6 \times 10^{5}\right.$ molecules $\left.\mathrm{cm}^{-3}\right)$ is largely improved.

Figure 4 shows the diurnal cycle of measured and modeled $\mathrm{HO}_{2}$ and $\mathrm{OH}$ reactivity between 20 June and 30 July 2009 near BFRS. In general both measured $\mathrm{HO}_{2}$ and $\mathrm{OH}$ reactivity are in good agreement with modeled values, although some large overestimates of $\mathrm{HO}_{2}$ were found for the model using the fast isomerization rates calculated by Peeters et al. (Peeters et al., 2009; Peeters and Müller, 2010) (Fig. S2). The difference between measured $\mathrm{OH}$ reactivity and the calculated $\mathrm{OH}$ reactivity from available measurements can be significantly improved by the inclusion of oxidation products from the model. We will further discuss these modelto-observation comparisons of $\mathrm{HO}_{2}$ and $\mathrm{OH}$ reactivity in the next section. 

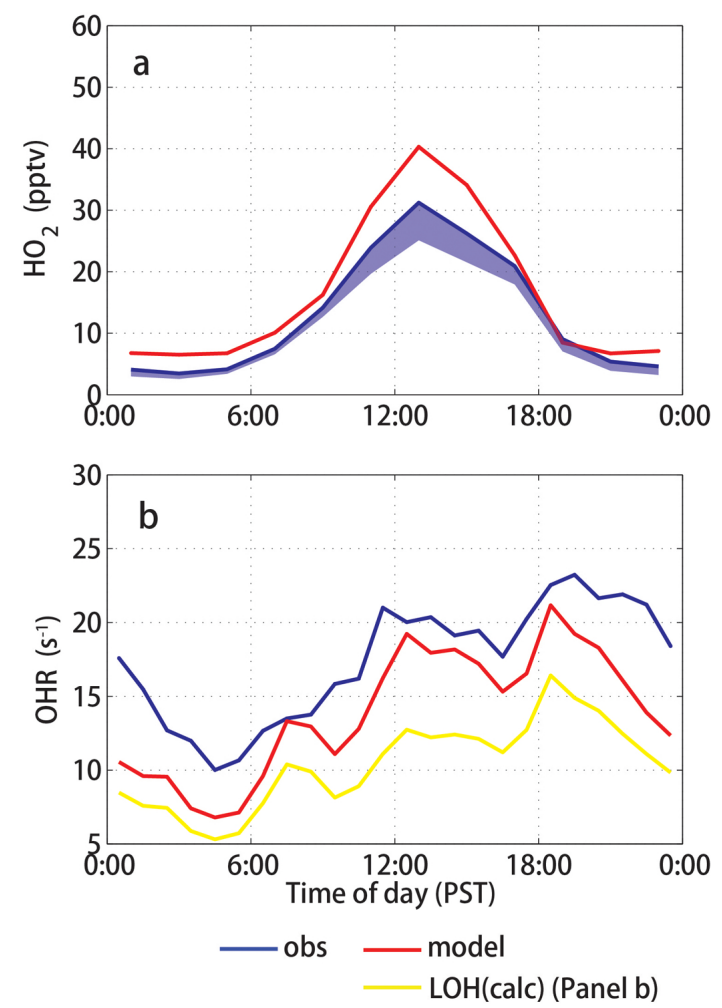

Fig. 4. Diurnal cycle of $\mathrm{HO}_{2}$ (a) and $\mathrm{OH}$ reactivity (b) between 20 June and 30 July 2009 near the Blodgett Forest Research Station (BFRS). In the top panel, the shaded area below measured $\mathrm{HO}_{2}$ (blue solid line) indicates the contribution to measured $\mathrm{HO}_{2}$ from an $\mathrm{RO}_{2}$ interference from isoprene, MVK and MACR (Fuchs et al., 2011). In the bottom panel, the calculated $\mathrm{OH}$ reactivity from available measurements (LOH) is represented by a yellow line. The absolute uncertainty of the $\mathrm{HO}_{2}$ measurements is $\pm 40 \%$ at $2 \sigma$ confidence. The absolute uncertainty of $\mathrm{OH}$ reactivity measurement is $1 \mathrm{~s}^{-1}$ at $2 \sigma$ confidence (Mao et al., 2009). The model incorporates the current understanding of BVOC oxidation chemistry (see text for details).

\subsection{Temperature dependence}

Another remarkable feature is the observed temperature dependence for the discrepancy between OHwave and OHchem (Fig. 5a). OHwave agrees with OHchem for temperatures near $295 \mathrm{~K}$ but becomes more than twice as large above $300 \mathrm{~K}$. The modeled $\mathrm{OH}$ has a smaller temperature dependence similar to that of OHchem. Interestingly, the difference between OHwave and $\mathrm{OHchem}$ correlates with the $\mathrm{OH}$ reactivity ( $r^{2}=0.94$ for binned median values in Fig. 6), suggesting that laboratory studies should focus on BVOCs or their oxidation products in a search to explain this interference. A question is "What causes this interference signal?"

The spectrum of the interference signal matched the $\mathrm{OH}$ spectrum, implying that some chemical enters the GTHOS and then rapidly produces $\mathrm{OH}$. After passing through the inlet hole, the sampled air experiences a supersonic isentropic
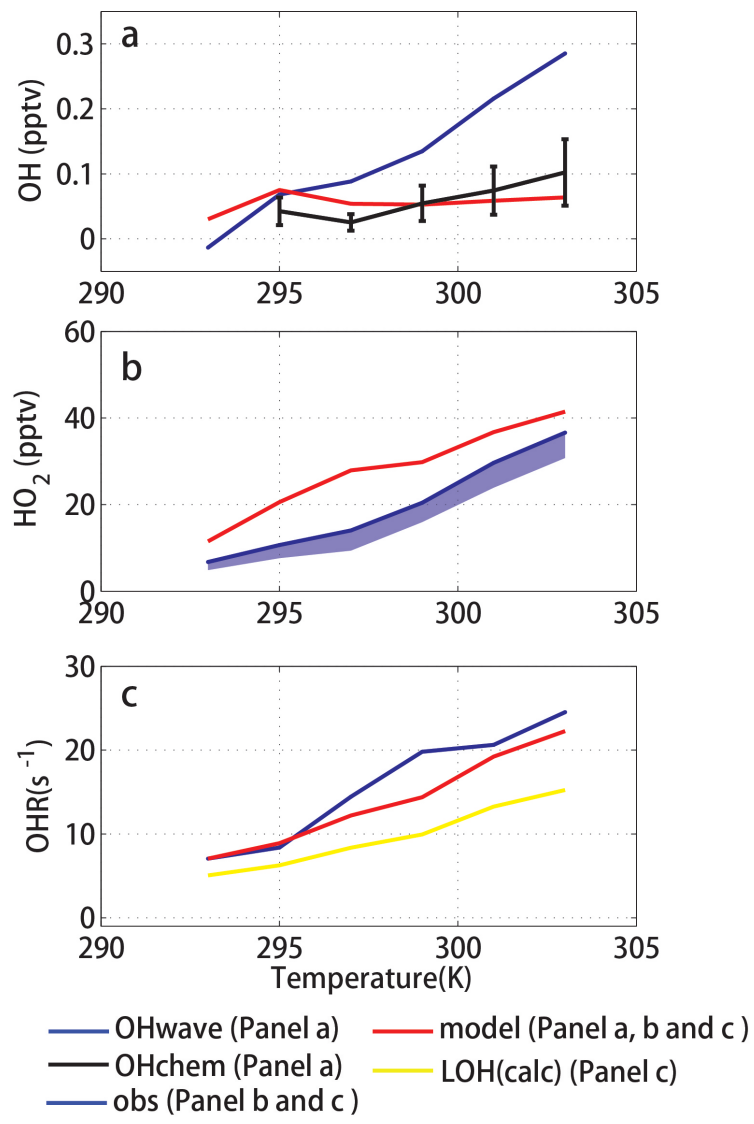

Fig. 5. Temperature dependence of (a) daytime measured and modeled $\mathrm{OH}$, (b) daytime measured and modeled $\mathrm{HO}_{2}$, and (c) $\mathrm{OH}$ reactivity between 9:00 and 15:00 PST during BEARPEX09. In (a), OHwave (blue line), OHchem (black line) and modeled $\mathrm{OH}$ (red line) agree at low temperature, but OHwave has a significant temperature increase while OHchem and modeled $\mathrm{OH}$ show little temperature dependence. The vertical bars indicate a combined uncertainty as described in Fig. 2. Note that OHchem here is corrected by 0.80 to account for the removal of internal $\mathrm{OH}$ by $\mathrm{C}_{3} \mathrm{~F}_{6}$ addition (see supplemental material). In (b), measured $\mathrm{HO}_{2}$ (blue line) is lower than modeled $\mathrm{HO}_{2}$ (red line) but not significantly at the low and high temperatures. Measured $\mathrm{HO}_{2}$ may be affected by an $\mathrm{RO}_{2}$ interference from isoprene, MVK and MACR (Fuchs et al., 2011), as indicated by the blue shading. In (c), the difference between the measured $\mathrm{OH}$ reactivity (blue line) and the $\mathrm{OH}$ reactivity calculated from available measurements (yellow line) suggests missing $\mathrm{OH}$ reactivity, which is mostly resolved when including modeled intermediates (red line) in the calculation.

gas expansion due to the sharp pressure change from one atmosphere to $\sim 5 \mathrm{hPa}$ and cools by more than $150 \mathrm{~K}$ (Stevens et al., 1994; Heal et al., 1995). The air then goes through a Mach disc and warms rapidly to approximately ambient temperature before it reaches the detection axis (Stevens et al., 1994; Heal et al., 1995). Such strong gradients of temperature and pressure could favor the dissociation of certain intermediate species. 


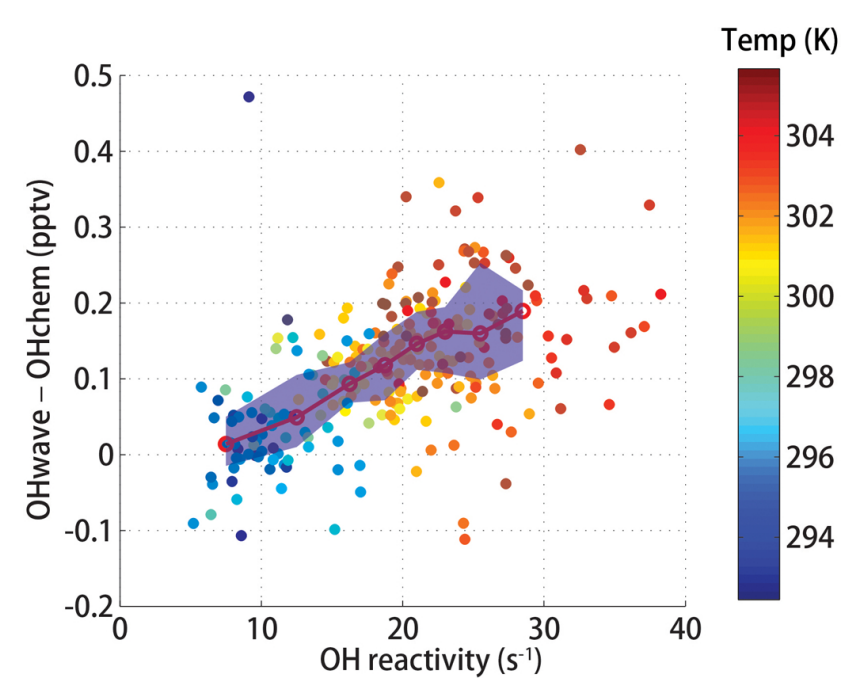

Fig. 6. Scatter plot between the measured $\mathrm{OH}$ reactivity and the difference between OHchem and OHwave between 09:00 and 15:00 PST. The 10-min averaged points are colored by the ambient temperature. The shaded blue area is the interquartile range of the data and the open circles are the median values in temperature bins.

Laboratory evidence indicates that some intermediate species from ozonolysis (Kurpius and Goldstein, 2003; Fares et al., 2010) tend to promptly decompose and produce $\mathrm{OH}$ at low pressure (Kroll et al., 2001; Donahue et al., 2011). Examples are the Criegee Intermediates and vinyl hydroperoxide (Herrmann et al., 2010), which promptly decompose on a short time scale $(<10 \mu \mathrm{s})$ (Zhang et al., 2002). It is also possible that such intermediate species come from other pathways. For instance, C5-hydroperoxyaldehydes (HPALDs), proposed by Peeters et al. (2009), appear to preferentially form at higher temperatures via peroxy radical isomerization for isoprene (Crounse et al., 2011). Of all of these possibilities, the decomposition of the stable Criegee Intermediate inside GTHOS appears to be the most likely candidate (Mauldin et al., 2012).

Such behavior may not be limited to isoprene. In BEARPEX09, MBO is the dominant species for $\mathrm{OH}$ loss due its local emission and high reactivity with $\mathrm{OH}$ $\left(6.3 \times 10^{-11}\right.$ molecules $\mathrm{cm}^{-3} \mathrm{~s}^{-1}$ at $\left.300 \mathrm{~K}\right)$ (Baasandorj and Stevens, 2007). Despite the similar structure to isoprene, the model treatment of MBO photooxidation is completely different in terms of radical propagation. No $\mathrm{OH}$-regenerating mechanism has been reported for the oxidation of MBO by OH (Carrasco et al., 2007; Chan et al., 2009). The mechanism proposed by Peeters et al. (Peeters et al., 2009; Peeters and Müller, 2010) is not applicable for MBO peroxy radicals as the H-shift isomerization (the main pathway for producing HPALDs and $\mathrm{HO}_{\mathrm{x}}$ ) requires that a 6- or 7-membered ring transition state can be formed between the peroxy radical and a labile hydrogen atom. Although no laboratory evidence currently supports any of these possibilities, a reason- able hypothesis is that the discrepancy between OHwave and OHchem is due to intermediate products that are commonly produced in the oxidation of different BVOCs.

Comparison of the measured and modeled $\mathrm{HO}_{2}$ provides an additional constraint on the model (Fig. S3b). Using the fast isomerization rates calculated by Peeters et al. (2009) and Peeters and Müller (2010), the box model calculated $\mathrm{HO}_{2}$ mixing ratios which are up to 3 times greater than the $\mathrm{HO}_{2}$ measurements (Fig. S3 in the Supplement), consistent with recent model-to-observation comparisons in other forest studies (Kanaya et al., 2012; Lu et al., 2011; Whalley et al., 2011). However, when the isomerization rate is reduced for the unimolecular isomerization channel in accordance with recent laboratory studies (Crounse et al., 2011), the $\mathrm{HO}_{2}$ from the Peeters mechanism comes into better agreement with the $\mathrm{HO}_{2}$ measurements (Fig. S3b in the Supplement). Slight overestimation of $\mathrm{HO}_{2}$ could be attributed to an efficient aerosol reactive uptake (Mao et al., 2012), which is not included in the box model.

Comparison of the measured and calculated $\mathrm{OH}$ reactivity, the inverse of the $\mathrm{OH}$ lifetime, is another constraint. In a previous forest field campaign (PROPHET, 1998 and 2000 ), the measured $\mathrm{OH}$ reactivity was greater than the $\mathrm{OH}$ reactivity calculated using all available measurements ( $\mathrm{Di}$ Carlo et al., 2004). This "missing OH reactivity" had a temperature dependence that matched the temperature dependence commonly used for the emission of terpenes, which is $\operatorname{mOHR}(\mathrm{T})=\operatorname{mOHR}(293) \cdot \exp (0.11 \cdot(\mathrm{T}-293))$, where $\mathrm{mOHR}$ represents missing $\mathrm{OH}$ reactivity. During BEARPEX09, the measured $\mathrm{OH}$ reactivity also exceeded that of the calculated $\mathrm{OH}$ reactivity from individual measured species (Fig. 5c). The difference between the measured $\mathrm{OH}$ reactivity and that calculated using only measured species during BEARPEX09 is $\operatorname{mOHR}(\mathrm{T})=\mathrm{mOHR}(293) \cdot \exp (0.168 \cdot(\mathrm{T}-293))$. However, if the calculated $\mathrm{OH}$ reactivity includes reactions with modeled BVOC oxidation products (Table 1), then the measured and modeled $\mathrm{OH}$ reactivity agree well within the uncertainties (Fig. 5c). Although MBO chemistry may not be well understood, the contribution of $\mathrm{OH}$ reactivity from modeled MBO oxidation products can still provide a useful and reasonable metric to constrain $\mathrm{OH}$ loss in the model. This agreement provides evidence that the missing $\mathrm{OH}$ reactivity is not mainly due to unmeasured BVOCs, such as unmeasured sesquiterpenes, but instead is due to oxidation products of measured BVOCs, consistent with recent investigations in the missing OH reactivity (Lou et al., 2010; Kim et al., 2011; Wolfe et al., 2011).

\section{Discussion and conclusions}

Several instrument comparisons for $\mathrm{OH}$ measurements have been conducted in the past two decades to quantify the possible errors in the understanding of radical chemistry. The airborne comparisons suggest a relatively good agreement 
Table 1. VOCs and other chemical species measured and used in the $\mathrm{OH}$ reactivity calculation. Also listed are the unmeasured but modeled species that could be major contributors to $\mathrm{OH}$ reactivity.

\begin{tabular}{lll}
\hline \multicolumn{3}{c}{ Measured species } \\
\hline$\alpha-$ Pinene & HCHO & Acetonitrile \\
$\beta$-Pinene & Acetaldehyde & $\mathrm{HNO}_{3}$ \\
Isoprene & Isoprene & MPAN \\
& hydroxyhydroperoxide & \\
Methylbutenol (MBO) & Glyoxal & $\mathrm{PAN}$ \\
Methyl vinyl ketone (MVK) & Glycolaldehyde & $\mathrm{PPN}$ \\
Methacrolein (MACR) & Hydroxyacetone & $\mathrm{NO}_{2}$ \\
Unidentified sesquiterpenes & Methanol & $\mathrm{CO}$ \\
Methyl Chavicol & Ethanol & $\mathrm{HONO}$ \\
Camphene & Butanol & $\mathrm{NO}$ \\
Acetone & Isobutyl alcohol & $\mathrm{O}_{3}$ \\
Benzene & Toluene & Butane \\
\hline
\end{tabular}

Unmeasured species as major contributors to $\mathrm{OH}$ reactivity

MBO oxidation products $(2.2)^{*}$

Isoprene epoxides (0.9)

C3 and higher aldehydes (1.6)

* The numbers in the brackets indicate the median $\mathrm{OH}$ loss rates at $303 \mathrm{~K}$ in the model with the units of $\mathrm{s}^{-1}$.

between two OH instruments. During the NASA PEM Tropics B aircraft campaign in 1999 , OH was measured by both Penn State LIF instrument on the NASA DC-8 aircraft and NCAR CIMS instrument on the NASA P-3B aircraft. These side-by-side flight intercomparisons show a ratio of LIF/CIMS OH from 0.8 near surface to 1.6 at $8 \mathrm{~km}$ (Eisele et al., 2001). During the NASA TRACE-P aircraft campaign in 2001, the same two instruments show a ratio of LIF/CIMS OH roughly 0.7 for three legs of flight intercomparisons between 0.2 and $5.3 \mathrm{~m}$ (Eisele et al., 2003), although this bias from TRACE-P intercomparisons is resolved by the revision of the ATHOS calibration factor by a factor of 1.64 for measurements from 2001 to 2006 (Ren et al., 2008; Mao et al., 2010). A more recent aircraft intercomparison was conducted during the NASA ARTCAS aircraft campaign, in which the same two instruments were both installed on NASA DC-8 aircraft and therefore provides a far more detailed examination. During ARCTAS, the campaignaverage ratio of LIF/CIMS OH is 1.27 , suggesting a reasonably good agreement for the two instruments in a clean atmosphere (Ren et al., 2012).

Ground comparisons for $\mathrm{OH}$ measurements were conducted in both ambient air and chamber tests. For chamber tests and clean air in rural sites, good agreement was achieved between LIF instruments and DOAS instruments, including POPCORN field campaign (Brauers et al., 1996), and SAPHIR chamber tests (Schlosser et al., 2007; Schlosser et al., 2009). In addition, these intercomparisons provide evidence for no interference from ozone photolysis inside the LIF instruments, consistent with our tests. For a forest atmosphere, however, a persistent discrepancy was revealed between CIMS instrument and three LIF instruments, in which CIMS measured $\mathrm{OH}$ is less than all other LIF measured $\mathrm{OH}$ by $30-40 \%$ (Table 4 in Schlosser et al. 2009). In fact, isoprene concentrations mainly ranged between 0.3 and $0.6 \mathrm{ppb}$ during the intercomparison period for that study (Schlosser et al. 2009), far less than the biogenic VOC level encountered in BEARPEX09 (Table S1). Therefore it is possible that the discrepancy could be larger in a BEARPEX09-like forest.

Furthermore, a recent intercomparison study in SAPHIR chamber between LIF and DOAS instrument also shows a positive bias by $30-40 \%$ from LIF instrument for several VOC species (MVK and aromatics), but not others (isoprene and MACR) (Fuchs et al., 2012). Further tests for terpenes and other BVOCs are required to quantify the possible interference.

Another difference between our study and these chamber tests could be the level of scavengers for stable Criegee Intermediates, including $\mathrm{NO}_{2}$ and $\mathrm{SO}_{2}$. A recent laboratory study suggests unexpectedly rapid reactions of Criegee Intermediates with $\mathrm{NO}_{2}$ and $\mathrm{SO}_{2}$ (Welz et al., 2012). Given that $\mathrm{NO}_{2}$ amounts in the chamber tests (1-2 ppb) (Fuchs et al., 2012) were significantly higher than the amounts during BEARPEX09 ( $200 \mathrm{ppt})$, the stable Criegee Intermediates could be suppressed by $\mathrm{NO}_{2}$ in those chamber tests, leading to a smaller interference to be detected by their instruments.

The conclusion that OHchem is a measure of the real atmospheric $\mathrm{OH}$ is supported by indirect evidence from the BEARPEX07 study (http://www.ocf.berkeley.edu/ $\sim$ bearpex/), including the greatly improved agreement for acyl peroxy nitrates (LaFranchi et al., 2009) and glyoxal (Huisman et al., 2011) when the model is constrained with a scaled OHwave using the measured OHchem to OHwave ratios during BEARPEX09. Thus, these measurements of $\mathrm{OH}$, $\mathrm{HO}_{2}$, and $\mathrm{OH}$ reactivity are generally consistent with our understanding of BVOC oxidation chemistry as represented in the model with recent updates in BVOC oxidation mechanisms.

Laboratory studies are underway to identify the source of the difference between OHwave and OHchem. However, identifying the cause of the $\mathrm{OH}$ interference and determining its possible relevance to atmospheric processes will take some time. On the other hand, it is important for the chemistry modeling community to know that measurements of unexpectedly large $\mathrm{OH}$ may not be correct for all forested environments and that they should wait before implementing new BVOC oxidation chemistry in their models until the measurement issues are resolved.

Caution must be taken for applying this discrepancy to other LIF instruments. Instrument designs differ significantly among LIF instruments in terms of flow geometry, pumping speed, cell pressure, laser frequency and optical paths in the detection cell. These differences can cause differences in supersonic expansion, temperature profiles from inlet to the detection region, and flow residence time, which will lead to differences in the amount of internally produced $\mathrm{OH}$. This question could be answered by deploying the second method of $\mathrm{OH}$ measurement on other LIF instruments. 
This discrepancy may also vary across different forested environments. The levels of ozone, $\mathrm{OH}$, and amount and mix of BVOCs may all play a role in determining the difference between OHwave and OHchem and the ratio of OHchem/OHwave. In particular, in contrast to a mean of $54 \mathrm{ppb}$ ozone in BEARPEX09, observed daytime ozone in tropical forests can be as low as 10 to $20 \mathrm{ppb}$ (Lelieveld et al., 2008; Stone et al., 2011). Further investigation in a variety of forests with the same instruments is needed to test these hypotheses.

This consistency between measured $\mathrm{OH}, \mathrm{HO}_{2}$, and $\mathrm{OH}$ reactivity applies only to the Sierra Nevada forest in the BEARPEX09 study. It is not clear whether these findings also apply to other forest atmospheres or to the $\mathrm{OH}$ measurements with other FAGE-type instruments in other forests. Only measurements in those forest atmospheres with other FAGE-type instruments will resolve this question.

\section{Supplementary material related to this article is available online at: http://www.atmos-chem-phys.net/12/ 8009/2012/acp-12-8009-2012-supplement.pdf.}

Acknowledgements. We thank the reviewers for their insightful comments. We acknowledge the contributions from Philip Feiner, Jennifer Gielen, and Josh Magerman for $\mathrm{HO}_{\mathrm{x}}$ measurements and from Robin Weber for $\mathrm{CO}$ and $\mathrm{O}_{3}$ measurements during BEARPEX09 study. We also acknowledge William Stockwell and Wendy Goliff for the RACM2 mechanism. We thank Sierra Pacific Industries for the use of their land and the University of California, Berkeley, Center for Forestry, Blodgett Forest Research Station for cooperation in facilitating this research. We acknowledge the NSF Atmospheric Chemistry Program for the following grants: \#0849475 (WHB); \#0922562 (AHG); \#0852406 (FNK); \#0934408 (POW, JDC, and MRB).

Edited by: J. Williams

\section{References}

Bouvier-Brown, N. C., Goldstein, A. H., Gilman, J. B., Kuster, W. C., and de Gouw, J. A.: In-situ ambient quantification of monoterpenes, sesquiterpenes, and related oxygenated compounds during BEARPEX 2007: implications for gas- and particle-phase chemistry, Atmos. Chem. Phys., 9, 5505-5518, doi:10.5194/acp-9-5505-2009, 2009a.

Bouvier-Brown, N. C., Goldstein, A. H., Worton, D. R., Matross, D. M., Gilman, J. B., Kuster, W. C., Welsh-Bon, D., Warneke, C., de Gouw, J. A., Cahill, T. M., and Holzinger, R.: Methyl chavicol: characterization of its biogenic emission rate, abundance, and oxidation products in the atmosphere, Atmos. Chem. Phys., 9, 2061-2074, doi:10.5194/acp-9-2061-2009, 2009b.
Bouvier-Brown, N. C., Holzinger, R., Palitzsch, K., and Goldstein, A. H.: Large emissions of sesquiterpenes and methyl chavicol quantified from branch enclosure measurements, Atmos. Environ., 43, 389-401, doi:10.1016/j.atmosenv.2008.08.039, 2009c.

Brauers, T., Aschmutat, U., Brandenburger, U., Dorn, H., P, Hausmann, M., Heßling, M., Hofzumahaus, A., Holland, F., PlassDülmer, C., and Ehhalt, D. H.: Intercomparison of tropospheric $\mathrm{OH}$ radical measurements by multiple folded long path laser absorption and laser induced fluorescence, Geophys. Res. Lett., 23, 2545-2548, doi:10.1029/96g102204, 1996.

Butler, T. M., Taraborrelli, D., Fischer, C. B. H., Harder, H., Martinez, M., Williams, J., Lawrence, M. G., and Lelieveld, J.: Improved simulation of isoprene oxidation chemistry with the ECHAM5/MESSy chemistry-climate model: lessons from the GABRIEL airborne field campaign, Atmos. Chem. Phys., 8, 4529-4546, doi:10.5194/acp-8-4529-2008, 2008.

Carrasco, N., Doussin, J. F., O'Connor, M., Wenger, J. C., PicquetVarrault, B., Durand-Jolibois, R., and Carlier, P.: Simulation chamber studies of the atmospheric oxidation of 2-methyl3-buten-2-ol: Reaction with hydroxyl radicals and ozone under a variety of conditions, J. Atmos. Chem., 56, 33-55, doi:10.1007/s10874-006-9041-y, 2007.

Carslaw, N., Creasey, D. J., Harrison, D., Heard, D. E., Hunter, M. C., Jacobs, P. J., Jenkin, M. E., Lee, J. D., Lewis, A. C., Pilling, M. J., Saunders, S. M., and Seakins, P. W.: $\mathrm{OH}$ and $\mathrm{HO}_{2}$ radical chemistry in a forested region of north-western Greece, Atmos. Environ., 35, 4725-4737, 2001.

Chan, A. W. H., Galloway, M. M., Kwan, A. J., Chhabra, P. S., Keutsch, F. N., Wennberg, P. O., Flagan, R. C., and Seinfeld, J. H.: Photooxidation of 2-Methyl-3-Buten-2-ol (MBO) as a Potential Source of Secondary Organic Aerosol, Environ. Sci. Technol., 43, 4647-4652, doi:10.1021/es802560w, 2009.

Crounse, J. D., Paulot, F., Kjaergaard, H. G., and Wennberg, P. O.: Peroxy radical isomerization in the oxidation of isoprene, Phys. Chem. Chem. Phys., 13, 13607-13613, doi:10.1039/C1CP21330J, 2011.

Di Carlo, P., Brune, W. H., Martinez, M., Harder, H., Lesher, R., Ren, X. R., Thornberry, T., Carroll, M. A., Young, V., Shepson, P. B., Riemer, D., Apel, E., and Campbell, C.: Missing OH reactivity in a forest: Evidence for unknown reactive biogenic VOCs, Science, 304, 722-725, 2004.

Donahue, N. M., Drozd, G. T., Epstein, S. A., Presto, A. A., and Kroll, J. H.: Adventures in ozoneland: down the rabbit-hole, Phys. Chem. Chem. Phys., 13, 10848-10857, 2011.

Dreyfus, G. B., Schade, G. W., and Goldstein, A. H.: Observational constraints on the contribution of isoprene oxidation to ozone production on the western slope of the Sierra Nevada, California, J. Geophys. Res.-Atmos., 107, 4365, doi:10.1029/2001jd001490, 2002.

Dubey, M. K., Hanisco, T. F., Wennberg, P. O., and Anderson, J. G.: Monitoring potential photochemical interference in laserinduced fluorescence measurements of atmospheric $\mathrm{OH}$, Geophys. Res. Lett., 23, 3215-3218, 1996.

Eisele, F. L., Mauldin, R. L., Tanner, D. J., Cantrell, C., Kosciuch, E., Nowak, J. B., Brune, B., Faloona, I., Tan, D., Davis, D. D., Wang, L., and Chen, G.: Relationship between $\mathrm{OH}$ measurements on two different NASA aircraft during PEM Tropics B, J. Geophys. Res.-Atmos., 106, 32683-32689, 2001. 
Eisele, F. L., Mauldin, L., Cantrell, C., Zondlo, M., Apel, E., Fried, A., Walega, J., Shetter, R., Lefer, B., Flocke, F., Weinheimer, A., Avery, M., Vay, S., Sachse, G., Podolske, J., Diskin, G., Barrick, J. D., Singh, H. B., Brune, W., Harder, H., Martinez, M., Bandy, A., Thornton, D., Heikes, B., Kondo, Y., Riemer, D., Sandholm, S., Tan, D., Talbot, R., and Dibb, J.: Summary of measurement intercomparisons during TRACE-P, J. Geophys. Res., 108, 8791, doi:10.1029/2002jd003167, 2003.

Faloona, I., Tan, D., Brune, W., Hurst, J., Barket, D., Couch, T. L., Shepson, P., Apel, E., Riemer, D., Thornberry, T., Carroll, M. A., Sillman, S., Keeler, G. J., Sagady, J., Hooper, D., and Paterson, K.: Nighttime observations of anomalously high levels of hydroxyl radicals above a deciduous forest canopy, J. Geophys. Res.-Atmos., 106, 24315-24333, 2001.

Faloona, I. C., Tan, D., Lesher, R. L., Hazen, N. L., Frame, C. L., Simpas, J. B., Harder, H., Martinez, M., Di Carlo, P., Ren, X. R., and Brune, W. H.: A laser-induced fluorescence instrument for detecting tropospheric $\mathrm{OH}$ and $\mathrm{HO}_{2}$ : Characteristics and calibration, J. Atmos. Chem., 47, 139-167, 2004.

Fares, S., McKay, M., Holzinger, R., and Goldstein, A. H.: Ozone fluxes in a Pinus ponderosa ecosystem are dominated by non-stomatal processes: Evidence from long-term continuous measurements, Agric. For. Meteorol., 150, 420-431, doi:10.1016/j.agrformet.2010.01.007, 2010.

Fuchs, H., Bohn, B., Hofzumahaus, A., Holland, F., Lu, K. D., Nehr, S., Rohrer, F., and Wahner, A.: Detection of $\mathrm{HO}_{2}$ by laserinduced fluorescence: calibration and interferences from $\mathrm{RO} 2$ radicals, Atmos. Meas. Tech., 4, 1209-1225, doi:10.5194/amt4-1209-2011, 2011.

Fuchs, H., Dorn, H.-P., Bachner, M., Bohn, B., Brauers, T., Gomm, S., Hofzumahaus, A., Holland, F., Nehr, S., Rohrer, F., Tillmann, R., and Wahner, A.: Comparison of $\mathrm{OH}$ concentration measurements by DOAS and LIF during SAPHIR chamber experiments at high $\mathrm{OH}$ reactivity and low NO concentration, Atmos. Meas. Tech., 5, 1611-1626, doi:10.5194/amt-5-1611-2012, 2012.

Hansen, M. C., DeFries, R. S., Townshend, J. R. G., Carroll, M., Dimiceli, C., and Sohlberg, R. A.: Global Percent Tree Cover at a Spatial Resolution of 500 Meters: First Results of the MODIS Vegetation Continuous Fields Algorithm, Earth Interactions, 7, 1-15, 2003.

Hard, T. M., O’Brien, R. J., Chan, C. Y., and Mehrabzadeh, A. A.: Tropospheric free radical determination by fluorescence assay with gas expansion, Environ. Sci. Technol., 18, 768-777, doi:10.1021/es00128a009, 1984.

Heal, M. R., Heard, D. E., Pilling, M. J., and Whitaker, B. J.: On the Development and Validation of FAGE for Local Measurement of Tropospheric $\mathrm{OH}$ and $\mathrm{HO}_{2}$, J. Atmos. Sci., 52, 3428-3441, 1995.

Henderson, B. H., Pinder, R. W., Crooks, J., Cohen, R. C., Hutzell, W. T., Sarwar, G., Goliff, W. S., Stockwell, W. R., Fahr, A., Mathur, R., Carlton, A. G., and Vizuete, W.: Evaluation of simulated photochemical partitioning of oxidized nitrogen in the upper troposphere, Atmos. Chem. Phys., 11, 275-291, doi:10.5194/acp-11-275-2011, 2011.

Herrmann, F., Winterhalter, R., Moortgat, G. K., and Williams, J.: Hydroxyl radical $(\mathrm{OH})$ yields from the ozonolysis of both double bonds for five monoterpenes, Atmos. Environ., 44, 3458-3464, doi:10.1016/j.atmosenv.2010.05.011, 2010.

Hofzumahaus, A., Rohrer, F., Lu, K. D., Bohn, B., Brauers, T., Chang, C. C., Fuchs, H., Holland, F., Kita, K., Kondo, Y., Li,
X., Lou, S. R., Shao, M., Zeng, L. M., Wahner, A., and Zhang, Y. H.: Amplified Trace Gas Removal in the Troposphere, Science, 324, 1702-1704, doi:10.1126/science.1164566, 2009.

Holzinger, R., Lee, A., Paw, K. T., and Goldstein, U. A. H.: Observations of oxidation products above a forest imply biogenic emissions of very reactive compounds, Atmos. Chem. Phys., 5, 67-75, doi:10.5194/acp-5-67-2005, 2005.

Huisman, A. J., Hottle, J. R., Galloway, M. M., DiGangi, J. P., Coens, K. L., Choi, W., Faloona, I. C., Gilman, J. B., Kuster, W. C., de Gouw, J., Bouvier-Brown, N. C., Goldstein, A. H., LaFranchi, B. W., Cohen, R. C., Wolfe, G. M., Thornton, J. A., Docherty, K. S., Farmer, D. K., Cubison, M. J., Jimenez, J. L., Mao, J., Brune, W. H., and Keutsch, F. N.: Photochemical modeling of glyoxal at a rural site: observations and analysis from BEARPEX 2007, Atmos. Chem. Phys., 11, 8883-8897, doi:10.5194/acp-11-88832011, 2011.

Kanaya, Y., Hofzumahaus, A., Dorn, H.-P., Brauers, T., Fuchs, H., Holland, F., Rohrer, F., Bohn, B., Tillmann, R., Wegener, R., Wahner, A., Kajii, Y., Miyamoto, K., Nishida, S., Watanabe, K., Yoshino, A., Kubistin, D., Martinez, M., Rudolf, M., Harder, H., Berresheim, H., Elste, T., Plass-Dülmer, C., Stange, G., K1effmann, J., Elshorbany, Y., and Schurath, U.: Comparisons of observed and modeled $\mathrm{OH}$ and $\mathrm{HO}_{2}$ concentrations during the ambient measurement period of the $\mathrm{HO}_{\mathrm{x}}$ Comp field campaign, Atmos. Chem. Phys., 12, 2567-2585, doi:10.5194/acp-12-25672012, 2012.

Karl, T., Harley, P., Emmons, L., Thornton, B., Guenther, A., Basu, C., Turnipseed, A., and Jardine, K.: Efficient Atmospheric Cleansing of Oxidized Organic Trace Gases by Vegetation, Science, 330, 816-819, doi:10.1126/science.1192534, 2010.

Kim, S., Guenther, A., Karl, T., and Greenberg, J.: Contributions of primary and secondary biogenic VOC tototal $\mathrm{OH}$ reactivity during the CABINEX (Community Atmosphere-Biosphere INteractions Experiments)-09 field campaign, Atmos. Chem. Phys., 11, 8613-8623, doi:10.5194/acp-11-8613-2011, 2011.

Kroll, J. H., Sahay, S. R., Anderson, J. G., Demerjian, K. L., and Donahue, N. M.: Mechanism of $\mathrm{HO}_{\mathrm{x}}$ Formation in the Gas-Phase Ozone-Alkene Reaction. 2. Prompt versus Thermal Dissociation of Carbonyl Oxides to Form OH, J. Phys. Chem. A, 105, 44464457, doi:10.1021/jp004136v, 2001.

Kurpius, M. R. and Goldstein, A. H.: Gas-phase chemistry dominates $\mathrm{O}_{3}$ loss to a forest, implying a source of aerosols and hydroxyl radicals to the atmosphere, Geophys. Res. Lett., 30, 1371, doi:10.1029/2002gl016785, 2003.

LaFranchi, B. W., Wolfe, G. M., Thornton, J. A., Harrold, S. A., Browne, E. C., Min, K. E., Wooldridge, P. J., Gilman, J. B., Kuster, W. C., Goldan, P. D., de Gouw, J. A., McKay, M., Goldstein, A. H., Ren, X., Mao, J., and Cohen, R. C.: Closing the peroxy acetyl nitrate budget: observations of acyl peroxy nitrates (PAN, PPN, and MPAN) during BEARPEX 2007, Atmos. Chem. Phys., 9, 7623-7641, doi:10.5194/acp-9-7623-2009, 2009.

Lelieveld, J., Butler, T. M., Crowley, J. N., Dillon, T. J., Fischer, H., Ganzeveld, L., Harder, H., Lawrence, M. G., Martinez, M., Taraborrelli, D., and Williams, J.: Atmospheric oxidation capacity sustained by a tropical forest, Nature, 452, 737-740, doi:10.1038/nature06870, 2008.

Lou, S., Holland, F., Rohrer, F., Lu, K., Bohn, B., Brauers, T., Chang, C. C., Fuchs, H., Häseler, R., Kita, K., Kondo, Y., Li, X., Shao, M., Zeng, L., Wahner, A., Zhang, Y., Wang, 
W., and Hofzumahaus, A.: Atmospheric $\mathrm{OH}$ reactivities in the Pearl River Delta - China in summer 2006: measurement and model results, Atmos. Chem. Phys., 10, 11243-11260, doi:10.5194/acp-10-11243-2010, 2010.

Lu, K. D., Rohrer, F., Holland, F., Fuchs, H., Bohn, B., Brauers, T., Chang, C. C., Häseler, R., Hu, M., Kita, K., Kondo, Y., Li, X., Lou, S. R., Nehr, S., Shao, M., Zeng, L. M., Wahner, A., Zhang, Y. H., and Hofzumahaus, A.: Observation and modelling of $\mathrm{OH}$ and $\mathrm{HO}_{2}$ concentrations in the Pearl River Delta 2006: a missing $\mathrm{OH}$ source in a VOC rich atmosphere, Atmos. Chem. Phys., 12, 1541-1569, doi:10.5194/acp-12-1541-2012, 2012.

Mao, J., Ren, X., Brune, W. H., Olson, J. R., Crawford, J. H., Fried, A., Huey, L. G., Cohen, R. C., Heikes, B., Singh, H. B., Blake, D. R., Sachse, G. W., Diskin, G. S., Hall, S. R., and Shetter, R. E.: Airborne measurement of $\mathrm{OH}$ reactivity during INTEX-B, Atmos. Chem. Phys., 9, 163-173, doi:10.5194/acp-9-163-2009, 2009.

Mao, J., Ren, X., Chen, S., Brune, W. H., Chen, Z., Martinez, M., Harder, H., Lefer, B., Rappenglueck, B., Flynn, J., and Leuchner, M.: Atmospheric oxidation capacity in the summer of Houston 2006: Comparison with summer measurements in other metropolitan studies, Atmos. Environ., 44, 4107-4115, doi:10.1016/j.atmosenv.2009.01.013, 2010.

Mao, J., Fan, S., Jacob, D., and Travis, K.: Radical loss in the atmosphere from $\mathrm{Cu}-\mathrm{Fe}$ redox coupling in aerosols, submitted, 2012.

Mauldin, R. L., Berndt, T., Sipila, M., Paasonen, P., Petaja, T., Kim, S., Kurten, T., Stratmann, F., Kerminen, V. M., and Kulmala, M.: A new atmospherically relevant oxidant of sulphur dioxide, Nature, 488, 193-196, 2012.

Paulot, F., Crounse, J. D., Kjaergaard, H. G., Kroll, J. H., Seinfeld, J. H., and Wennberg, P. O.: Isoprene photooxidation: new insights into the production of acids and organic nitrates, Atmos. Chem. Phys., 9, 1479-1501, doi:10.5194/acp-9-1479-2009, 2009a.

Paulot, F., Crounse, J. D., Kjaergaard, H. G., Kurten, A., St Clair, J. M., Seinfeld, J. H., and Wennberg, P. O.: Unexpected Epoxide Formation in the Gas-Phase Photooxidation of Isoprene, Science, 325, 730-733, doi:10.1126/science.1172910, 2009b.

Peeters, J., Nguyen, T. L., and Vereecken, L.: $\mathrm{HO}_{\mathrm{x}}$ radical regeneration in the oxidation of isoprene, Phys. Chem. Chem. Phys., 11, 5935-5939, doi:10.1039/b908511d, 2009.

Peeters, J. and Müller, J. F.: $\mathrm{HO}_{\mathrm{x}}$ radical regeneration in isoprene oxidation via peroxy radical isomerisations. II: experimental evidence and global impact, Phys. Chem. Chem. Phys., 12, 1422714235, doi:10.1039/c0cp00811g, 2010.

Ren, X., Mao, J., Brune, W. H., Cantrell, C. A., Mauldin III, R. L., Hornbrook, R. S., Kosciuch, E., Olson, J. R., Crawford, J. H., Chen, G., and Singh, H. B.: Airborne intercomparison of $\mathrm{HO}_{\mathrm{x}}$ measurements using laser-induced fluorescence and chemical ionization mass spectrometry during ARCTAS, Atmos. Meas. Tech., 5, 2025-2037, doi:10.5194/amt-5-2025-2012, 2012.

Ren, X. R., Harder, H., Martinez, M., Faloona, I. C., Tan, D., Lesher, R. L., Di Carlo, P., Simpas, J. B., and Brune, W. H.: Interference testing for atmospheric $\mathrm{HO}_{\mathrm{x}}$ measurements by laser-induced fluorescence, J. Atmos. Chem., 47, 169-190, 2004.

Ren, X. R., Olson, J. R., Crawford, J. H., Brune, W. H., Mao, J. Q., Long, R. B., Chen, Z., Chen, G., Avery, M. A., Sachse, G. W., Barrick, J. D., Diskin, G. S., Huey, L. G., Fried, A., Cohen, R. C., Heikes, B., Wennberg, P. O., Singh, H. B., Blake, D. R., and Shetter, R. E.: $\mathrm{HO}_{\mathrm{x}}$ chemistry during INTEX-A 2004: Observation, model calculation, and comparison with previous studies, J. Geophys. Res.-Atmos., 113, D05310, doi:10.1029/2007jd009166, 2008.

Schade, G. W., Goldstein, A. H., Gray, D. W., and Lerdau, M. T.: Canopy and leaf level 2-methyl-3-buten-2-ol fluxes from a ponderosa pine plantation, Atmos. Environ., 34, 3535-3544, 2000.

Schlosser, E., Bohn, B., Brauers, T., Dorn, H.-P., Fuchs, H., Häseler, R., Hofzumahaus, A., Holland, F., Rohrer, F., Rupp, L., Siese, M., Tillmann, R., and Wahner, A.: Intercomparison of Two Hydroxyl Radical Measurement Techniques at the Atmosphere Simulation Chamber SAPHIR, J. Atmos. Chem., 56, 187-205, doi:10.1007/s10874-006-9049-3, 2007.

Schlosser, E., Brauers, T., Dorn, H. P., Fuchs, H., Häseler, R., Hofzumahaus, A., Holland, F., Wahner, A., Kanaya, Y., Kajii, Y., Miyamoto, K., Nishida, S., Watanabe, K., Yoshino, A., Kubistin, D., Martinez, M., Rudolf, M., Harder, H., Berresheim, H., Elste, T., Plass-Dülmer, C., Stange, G., and Schurath, U.: Technical Note: Formal blind intercomparison of $\mathrm{OH}$ measurements: results from the international campaign $\mathrm{HO}_{\mathrm{x}}$ Comp, Atmos. Chem. Phys., 9, 7923-7948, doi:10.5194/acp-9-7923-2009, 2009.

Smith, G. P. and Crosley, D. R.: A Photochemical Model of Ozone Interference Effects in Laser Detection of Tropospheric OH, J. Geophys. Res., 95, 16427-16442, doi:10.1029/JD095iD10p16427, 1990.

Steiner, A. L., Tonse, S., Cohen, R. C., Goldstein, A. H., and Harley, R. A.: Biogenic 2-methyl-3-buten-2-ol increases regional ozone and $\mathrm{HO}_{\mathrm{x}}$ sources, Geophys. Res. Lett., 34, L15806, doi:10.1029/2007g1030802, 2007.

Stevens, P. S., Mather, J. H., and Brune, W. H.: Measurement of tropospheric $\mathrm{OH}$ and $\mathrm{HO}_{2}$ by laser-induced fluorescence at low pressure, J. Geophys. Res., 99, 3543-3557, doi:10.1029/93jd03342, 1994.

Stockwell, W. R., Kirchner, F., Kuhn, M., and Seefeld, S.: A new mechanism for regional atmospheric chemistry modeling, J. Geophys. Res.-Atmos., 102, 25847-25879, 1997.

Stone, D., Evans, M. J., Edwards, P. M., Commane, R., Ingham, T., Rickard, A. R., Brookes, D. M., Hopkins, J., Leigh, R. J., Lewis, A. C., Monks, P. S., Oram, D., Reeves, C. E., Stewart, D., and Heard, D. E.: Isoprene oxidation mechanisms: measurements and modelling of $\mathrm{OH}$ and $\mathrm{HO}_{2}$ over a South-East Asian tropical rainforest during the OP3 field campaign, Atmos. Chem. Phys., 11, 6749-6771, doi:10.5194/acp-11-6749-2011, 2011.

Tan, D., Faloona, I., Simpas, J. B., Brune, W., Shepson, P. B., Couch, T. L., Sumner, A. L., Carroll, M. A., Thornberry, T., Apel, E., Riemer, D., and Stockwell, W.: $\mathrm{HO}_{\mathrm{x}}$ budgets in a deciduous forest: Results from the PROPHET summer 1998 campaign, J. Geophys. Res.-Atmos., 106, 24407-24427, 2001.

Tanner, D. J., Jefferson, A., and Eisele, F. L.: Selected ion chemical ionization mass spectrometric measurement of $\mathrm{OH}$, J. Geophys. Res., 102, 6415-6425, doi:10.1029/96jd03919, 1997.

Thornton, J. A., Wooldridge, P. J., Cohen, R. C., Martinez, M., Harder, H., Brune, W. H., Williams, E. J., Roberts, J. M., Fehsenfeld, F. C., Hall, S. R., Shetter, R. E., Wert, B. P., and Fried, A.: Ozone production rates as a function of NOx abundances and $\mathrm{HO}_{\mathrm{x}}$ production rates in the Nashville urban plume, J. Geophys. Res., 107, 4146, doi:10.1029/2001jd000932, 2002.

Welz, O., Savee, J. D., Osborn, D. L., Vasu, S. S., Percival, C. J., Shallcross, D. E., and Taatjes, C. A.: Direct Kinetic Measurements of Criegee Intermediate $\left(\mathrm{CH}_{2} \mathrm{OO}\right)$ Formed 
by Reaction of $\mathrm{CH}_{2} \mathrm{I}$ with $\mathrm{O}_{2}$, Science, 335, 204-207, doi:10.1126/science.1213229, 2012.

Whalley, L. K., Edwards, P. M., Furneaux, K. L., Goddard, A., Ingham, T., Evans, M. J., Stone, D., Hopkins, J. R., Jones, C. E., Karunaharan, A., Lee, J. D., Lewis, A. C., Monks, P. S., Moller, S. J., and Heard, D. E.: Quantifying the magnitude of a missing hydroxyl radical source in a tropical rainforest, Atmos. Chem. Phys., 11, 7223-7233, doi:10.5194/acp-11-7223-2011, 2011.

Wolfe, G. M. and Thornton, J. A.: The Chemistry of AtmosphereForest Exchange (CAFE) Model - Part 1: Model description and characterization, Atmos. Chem. Phys., 11, 77-101, doi:10.5194/acp-11-77-2011, 2011.
Wolfe, G. M., Thornton, J. A., Bouvier-Brown, N. C., Goldstein, A. H., Park, J. H., McKay, M., Matross, D. M., Mao, J., Brune, W. H., LaFranchi, B. W., Browne, E. C., Min, K. E., Wooldridge, P. J., Cohen, R. C., Crounse, J. D., Faloona, I. C., Gilman, J. B., Kuster, W. C., de Gouw, J. A., Huisman, A., and Keutsch, F. N.: The Chemistry of Atmosphere-Forest Exchange (CAFE) Model - Part 2: Application to BEARPEX-2007 observations, Atmos. Chem. Phys., 11, 1269-1294, doi:10.5194/acp-11-12692011, 2011.

Zhang, D., Lei, W. F., and Zhang, R. Y.: Mechanism of OH formation from ozonolysis of isoprene: kinetics and product yields, Chem. Phys. Lett., 358, 171-179, 2002. 